\title{
Folk Beliefs and Practices of Bagong (Amorphophallus sp.) farmers in San Roque, Northern Samar
}

\author{
Rhodora Abalajen-Bande $^{1 *}$ and Michael Carlo C. Villas ${ }^{2}$
}

\begin{abstract}
This study investigated the folk beliefs and practices of bagong farmers of San Roque, a coastal town 29 kilometers from Catarman, the capital town of Northern Samar. Going by Spanish sources, initial readings suggest that bagong, a root crop of genus Amorphophallus, has long been cultivated in Samar (Alcina 1668/2005). Unlike in other parts of the country where the plant is primarily utilized for pig feeding, the bagong in San Roque is served during special occasions like Christmas and New Year. These occasions are preceded by folk practices unique to the community. This study documents bagong farming and analyzes folk practices, with their attendant narratives and beliefs. Ethnographic observations and interviews were conducted among farmers and townsfolk. Results of the study will have implications on cultural education and cultural policy formulation.
\end{abstract}

Keywords: Amorphophallus, Bagong production, Folk Beliefs and Practices, San Roque, Samar

\section{INTRODUCTION}

Bagong or Amorphophallus $s p$ has a long history of being used as traditional Chinese medicine and as food source in some parts of Asia (Krishna et al 2012 and Chua et al 2010). In Bangladesh, Amorphophallus is among the food items consumed during periods of food scarcity (Paul et al 2012). It is also classified as a famine food plant in southern Ethiopia (Guinand \& Lemessa 2001).

In the Philippines, bagong - which is also called pongapong - is neither commonly cultivated nor eaten by the regular Filipino. Dorugade et al (2015) claimed that Amorphophallus grows in the wild particularly in the Philippines and in some other southeast Asian countries. Farmers in Valencia, Negros Oriental confirmed that the plant is found in the wild and is only used for pig feeding.

1,2 Department of Liberal Arts and Behavioral Sciences, Visayas State University, Visca, Baybay City, Leyte

\footnotetext{
* Corresponding Author. Address: Department of Liberal Arts and Behavioral Sciences, Visayas State University, Visca, Baybay City, Leyte; Email: rhodora.bande@vsu.edu.ph DOI: $10.32945 /$ atr 4115.2019
} 
However, this is not the case in San Roque, Northern Samar - it is widely cultivated in this part of the country. Many farmers devote a portion of their farms to bagong farming, and the residents of San Roque consider the crop as the best among the root crops available in their locality.

Bagong is a root crop of social and religious significance to the people of San Roque. It is prominently associated with the Christmas season-a season of abundance-in San Roque, Northern Samar. Its planting and harvesting are marked by two important seasons in the Christian calendar: among locals, it is famous as inug-og nga bagong, a Christmas delicacy; among farmers, its planting is associated with the Lenten season.

In many farming communities in the Philippines, agriculture is interwoven with folk beliefs and practices. Some of these date back to as early as $1600 \mathrm{~s}$, eg. the farming rites in the Visayas recorded by Alcina (2005) in 1668. The anthropological literature provides sufficient proof that these practices continue to this day. The Ifugaos, for instance, still practice the hongan di page or the rice farming rituals (Dulawan 2005); the Bontocs of Northern Luzon have their own rice rituals as well (Litsinger et al 2009). Farmers in Claveria in Misamis Oriental even perform magical practices (Litsinger et al 2009) to ensure a good harvest. A closer look at these activities brings a deeper understanding of the agricultural communities to which they belong and allows a broader perception of human societies.

Samar and Leyte have their own share of folk beliefs and practices which persist to this day in many of its village communities. Some of these were documented by Richard Arens (1956, 1957 \& 1982) and by Jaime Polo (1983); however, there remains a lot to be recorded from the field. One of these is the folk beliefs and practices accompanying the cultivation of bagong or Amorphophallus. It is noteworthy that the root crop was recorded by Alcina in 1668, but aside from this, no documentation of its cultivation in the Philippines has ever been made elsewhere.

\section{METHODOLOGY}

A series of field work was conducted in San Roque to identify the barangays where majority of bagong cultivators reside. San Roque (Figure 1 ) is a $4^{\text {th }}$ class municipality in Northern Samar. It consists of 16 barangays, belongs to the $2^{\text {nd }}$ district of the province, and spans a total land area of 18,779 hectares (Municipal Planning and Development Office 2018). As of August 2015, it had a population of 30,580 (Philippine Statistics Authority 2016).

On the first day of field work, the researchers made a courtesy call at the mayor's office to inform the town chief executive that a research on bagong farming and its accompanying folk beliefs and practices was going to be conducted. As a result of this meeting, the researchers were able to easily access information on San Roque.

Five barangays-Balnasan, Balud, Bantayan, Coroconog, and Pagsangan-were later identified. Participants were selected using purposive sampling and snowballing technique. 
Folk Beliefs and Practices of Bagong

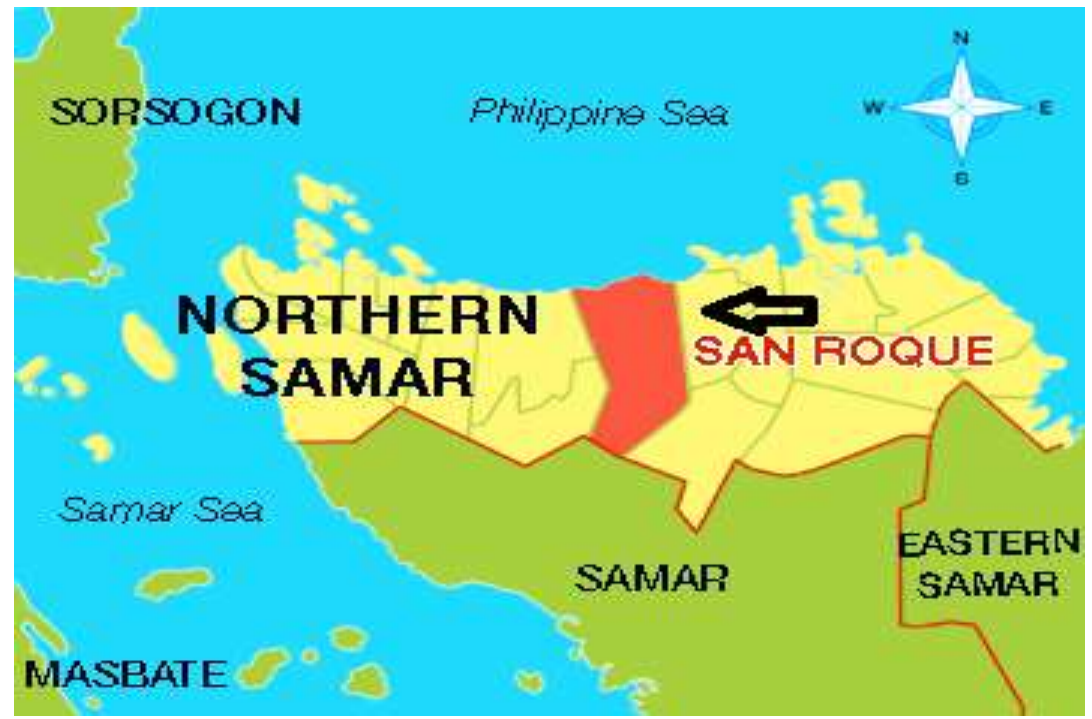

Figure 1. Map of Northern Samar showing the location of the municipality of San Roque

Data were collected using semi-structured interviews and field immersion/observation. The interview consisted of three parts: (1) the farmer's profile, (2) the farmer's knowledge about the root crop, and (3) the folk beliefs and practices associated with bagong. Pre-testing of the instrument was done in Barangay Coroconog and Barangay Balud prior to the actual data gathering. Field immersion was done during pre-planting, planting season, and harvesting season.

Data on farmer's profile were tabulated; the rest were collated and analyzed following the categories innovated by Richard Arens in his study of Leyte's rice ritual (1957). These categories were: rice planting ritual, rice harvesting ritual, rice storing, and animism in rice ritual. For the present study, the researchers created their own categories based on the data gathered.

\section{RESULTS AND DISCUSSION}

\section{Profile of Bagong Farmers}

Eighteen bagong farmers in San Roque, Northern Samar were interviewed for this study. Results show that the average age of the respondents was 57.11 years old (Table 1). The youngest belonged to the age bracket of $31-40$ years old $(5.56 \%)$; the oldest, to $81-90$ years old $(5.56 \%)$. Majority of the respondents were male (77.78\%) and married (77.78\%).

Results further reveal that $38.88 \%$ of the respondents had at least eleven years' experience of bagong farming; $16.66 \%$ had at least 41 years; and $5.56 \%$, at least 51 years. Average number of years in farming was 20.55 years.

Meanwhile, 33.33\% of the bagong farms were in Barangay Coroconog, and $22.22 \%$ were in Barangay Balnasan. The farms in Barangay Balud (22.22\%) were owned by farmers residing in the población. One farm (5.56\%), owned by a farmer in Barangay Balnasan, was in Barangay Canhumadal in Pambujan, the municipality 
next to San Roque.

All the respondents claimed that bagong has been cultivated for at least one hundred years along the coastal areas of what is now known as the municipality of San Roque. The respondents said that their parents or grandparents were bagong cultivators. According to the oldest respondents (44.44\%), even during World War II, bagong cultivation in San Roque did not stop.

Table 1. Socio-demographic profile of the respondents

\begin{tabular}{|c|c|c|}
\hline Variable & Number & Percentage (\%) \\
\hline \multicolumn{3}{|l|}{ Age } \\
\hline $31-40$ & 1 & 5.56 \\
\hline $41-50$ & 6 & 33.33 \\
\hline $51-60$ & 3 & 16.66 \\
\hline $61-70$ & 5 & 27.78 \\
\hline $71-80$ & 2 & 11.11 \\
\hline $81-90$ & 1 & 5.56 \\
\hline Total & 18 & 100.00 \\
\hline Average age of respondents: & 57.11 years old & \\
\hline \multicolumn{3}{|l|}{ Sex } \\
\hline Female & 4 & 22.22 \\
\hline Male & 14 & 77.78 \\
\hline Total & 18 & 100.00 \\
\hline \multicolumn{3}{|l|}{ Civil Status } \\
\hline Single & 0 & 0.00 \\
\hline Married & 14 & 77.78 \\
\hline Widow/Widower & 2 & 11.11 \\
\hline Live-in partnership & 2 & 11.11 \\
\hline Total & 18 & 100.00 \\
\hline \multicolumn{3}{|l|}{ Years in farming } \\
\hline $0-10$ & 5 & 27.78 \\
\hline $11-20$ & 7 & 38.88 \\
\hline $21-30$ & 1 & 5.56 \\
\hline $31-40$ & 1 & 5.56 \\
\hline $41-50$ & 3 & 16.66 \\
\hline $51-60$ & 1 & 5.56 \\
\hline Total & 18 & 100.00 \\
\hline Average number of years in farming: & 20.55 years & \\
\hline Variable & Number & Percentage (\%) \\
\hline \multicolumn{3}{|l|}{ Place of residence } \\
\hline Balnasan & 5 & 27.78 \\
\hline Balud & 0 & 0.00 \\
\hline Bantayan & 1 & 5.56 \\
\hline Coroconog & 6 & 33.33 \\
\hline Pagsang-an & 2 & 11.11 \\
\hline Poblacion & 4 & 22.22 \\
\hline Total & 18 & 100.00 \\
\hline \multicolumn{3}{|l|}{ Site of farm } \\
\hline Balnasan & 4 & 22.22 \\
\hline Balud & 4 & 22.22 \\
\hline Bantayan & 1 & 5.56 \\
\hline Canhumadal, Pambujan & 1 & 5.56 \\
\hline Coroconog & 6 & 33.33 \\
\hline Pagsang-an & 2 & 11.11 \\
\hline Total & 18 & 100.00 \\
\hline
\end{tabular}


Folk Beliefs and Practices of Bagong

\section{Household Members' Roles in Bagong Farming}

Bagong cultivation is usually a family activity. Wives accompany their husbands during the first planting of seeds, but they play a passive role during the event. The wife stays outside of the field while the husband performs the activities in the farm. Since it should be a quiet task, the husband conducts the activities alone. Later, in this paper, the ritual component of bagong cultivation will show the necessity of silence. The sons assist their fathers during field preparation, farm maintenance, harvesting, storing, and securing of seeds. The wives and their daughters are the ones in charge of cleaning the harvested crops and cooking the inug-og nga bagong, ie, bagong cooked in coconut milk and sugar. Meanwhile, both husband and wife are involved in monitoring the income and expenses of the farm.

From field preparation up to harvesting of the crop and securing the seeds, farmers follow folk beliefs and practices which they inherited from their ancestors and their community.

\section{Preparing the Field}

In Barangay Pagsang-an, most farmers follow this procedure: (1) arado (plow); (2) rudos (pulverize); (3) arado (plow); (4) rudos (pulverize); (5) arado (plow); (6) pabutbuton ito digtoy nga sighot (wait until the tiny weeds sprout); (7) rudos (pulverize); and (8) tudlingon (make a straight line to be used as a guide for planting).

Arado or plowing (Figure 2) is done traditionally with the aid of a carabao and its farm implement, the plow. To pulverize the soil, farmers use their bare hands; otherwise, they use a purang (bolo) or a landok (a digging bar).

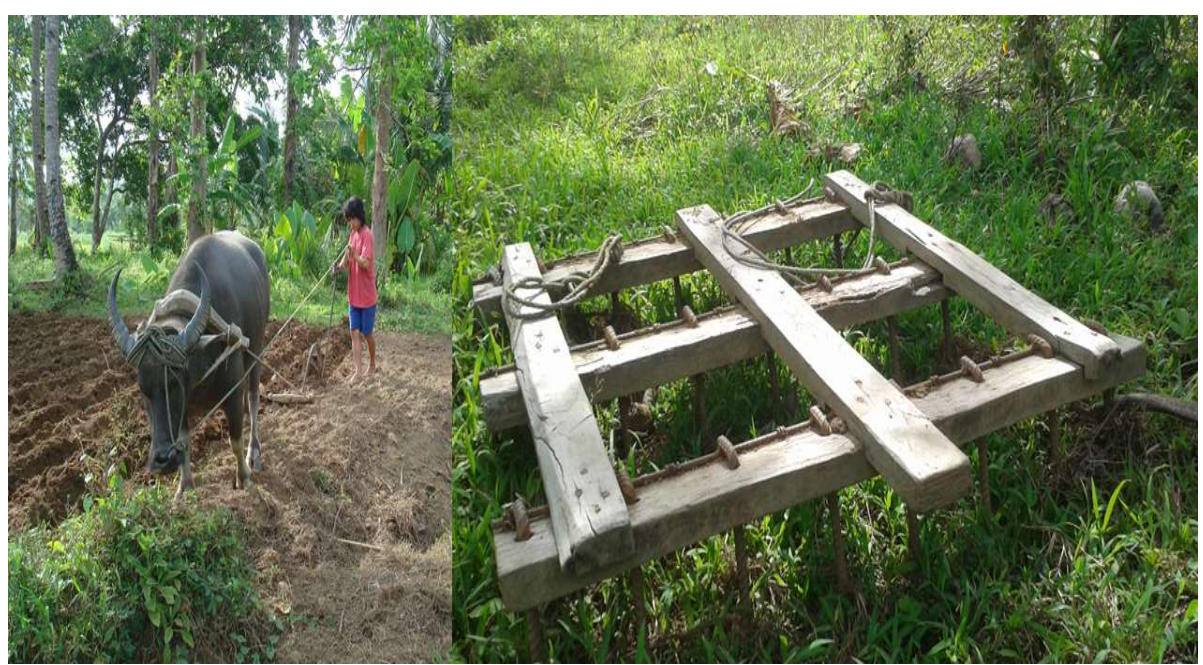

Figure 2. Left photo: plowing of the field; right photo: rastilyas, a harrowing device that is attached to the carabao so the latter will pull it and as a result, the soil will be smoothened 
Other farmers follow this procedure: (1) arado (plow); (2) rastilyas (Figure 2), para sumungaw a kapaso sa tuna (harrowing, so the heat of the soil will be released); and (3) duha ka rudos (pulverize, two times) before planting.

\section{Site Requirement}

The farmers describe the plant as himangrawon (mysterious) and hahawagon (has fear of heights) - the bagong of San Roque does not thrive in the forest and on elevated areas.

They call the wild bagong, or the bagong found in the forest or in the wild, banwaanon. In ordinary discourse, banwaanon and engkanto are used interchangeably; both words refer to a world that belongs to diri pareho sa at (people who are different from us). The word engkanto comes from the Spanish verb encanto which means "enchanted" (Demetrio 1969).

The banwaanon nga bagong (wild bagong) is inedible. One respondent related that he tried eating a wild bagong he found in Doña Carmen Subdivision in Fairview, Quezon City in the late 1960s. He cooked it as inug-og and served it to his family. A few minutes later, their bodies were gidarapi (red and itchy); their tongues, raputok (swollen).

When selecting the area where they should plant bagong, farmers see to it that they choose a patag nga lugar (flat ground). The farm should not be located on sloping and elevated land; otherwise, it will not thrive.

Bagong grows well on bagamban: a kind of soil that is neither galut (clayey) nor baras (sandy). It also grows well on areas where there is puti or talahib (Saccharum spontaneum). Hence, it is common for farmers to look for areas dominated by puti, so they can convert it to a bagong farm. They prepare the area by burning the grass first and by doing the sagaksak (clearing the area) next.

\section{Timing of Planting}

Tadok or the planting of the first set of butig, ie, tubers or the bagong planting materials is done during tiniblas. Tiniblas is the window of time between Miyerkules Santo (Holy Wednesday) and Biyernes Santo (Good Friday). It is derived from a Spanish word which means "utter darkness," referring to the dark hours during Christ's crucifixion. A folk belief associated with the tiniblas is that if one is wounded within this time, recovery will be difficult. The farmer leaves his home and heads to the farm between 8:00 o'clock in the morning until 12:00 noon. To the farmers, planting is not considered tadok if it is done outside of the period of tiniblas. Interestingly enough, tadok also means to light a candle in an upright position-what one does when one lights a candle at church during prayer.

The farmers also noted that tadok should be done during a kadayaw (full moon). Otherwise, the crop will not thrive. According to them, "Kun kadulom, maadab la; wara tayod" ("If it will be planted on a new moon, it will just be bushy; but there won't be any tuber").

Only a small portion-about 50 to 60 or sometimes 10 to $12-$ of the planting materials (Figure 3 ) are used during the tadok. The rest are planted the following week right after the tiniblas since they also have to meditate and observe silence during the week. The farmers said that tiniblas is closely associated with katsisibang or the time of the year when a samad maiha mabulong kay giraysang 
Folk Beliefs and Practices of Bagong

sa krus a Ginoo (wounds do not easily heal because the Lord is nailed on the cross). Thus, people are extra careful when it comes to doing farm work or other strenuous activities during this time.

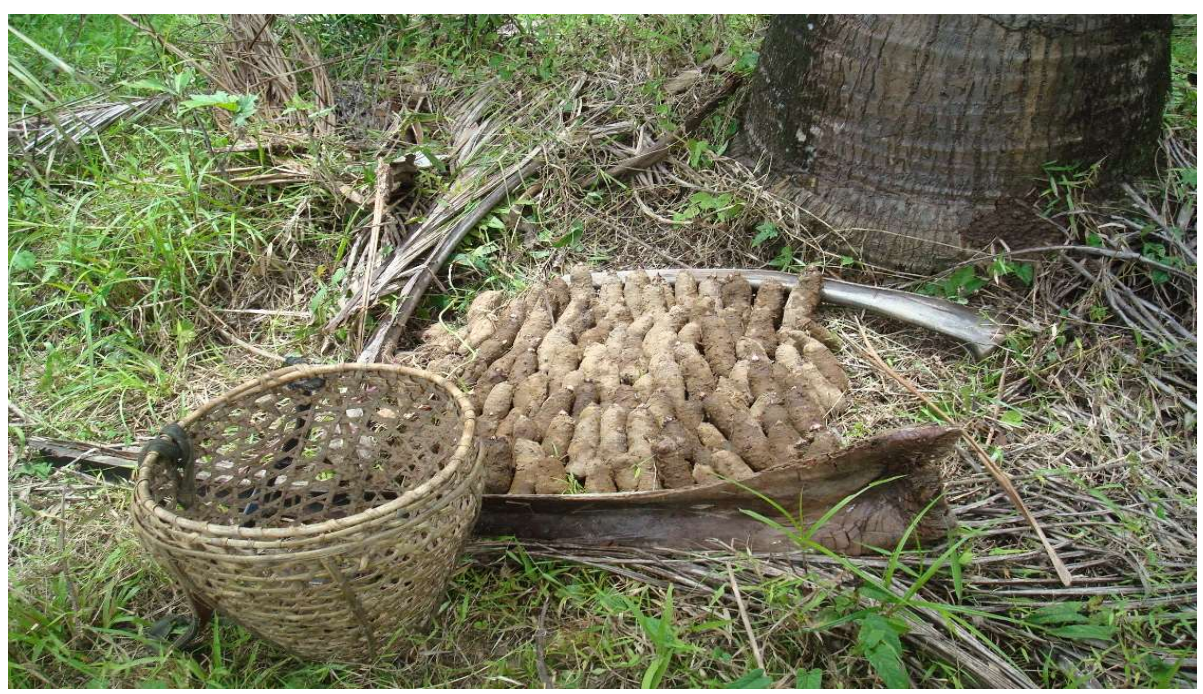

Figure 3. The planting materials right before the tadok in Brgy. Pagsang-an

\section{Planting Ritual}

Before doing the tadok, a sariak or an installation made of bamboo (Figure 4) is placed in the middle of the farm. A coconut fruit is placed on top of the installation while a sugarcane cutting and a dulaw or turmeric are planted beside it.

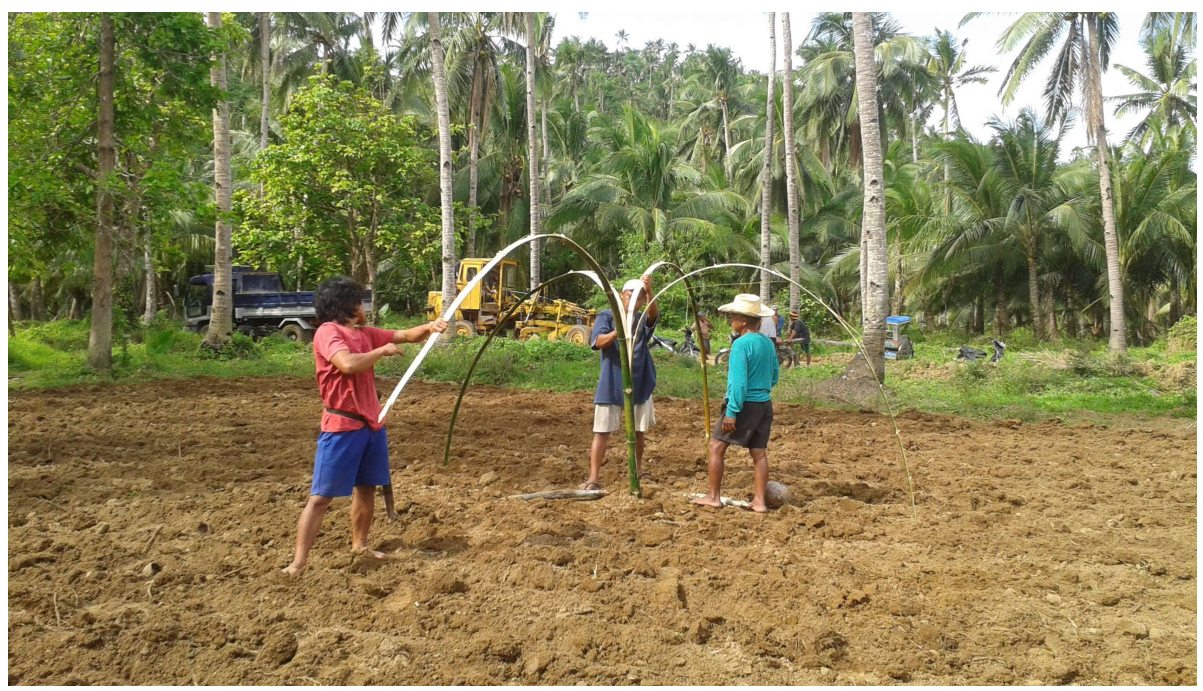

Figure 4. A farmer (in green shirt) in Brgy. Balud is assisted by his sons in installing the sariak 
While putting the installation, the farmer whispers a prayer:

\author{
Himulong ito bagong \\ sito dulaw nga dulaw \\ a tayod sabagong. \\ Himulong ito bagong \\ sito lubi, dako ngan matam-is. \\ Himulong ito bagong \\ sito sariak, nabuklad
}

(May the bagong/ be like the dulaw, / may its flesh be yellow. / May the bagong/ be like the coconut, / big and sweet. / May the bagong/ be like the sariak, / its leaves wide open).

He further adds: "Magkatol man a bagong, magkatol man 'to tubo" [If the bagong will cause itchiness (to its eaters), may the sugarcane cause itchiness also]. One farmer explained that sugarcane will never cause itchiness, so it is a good antidote for itching.

A note on the term, "himulong," which begins the prayer: its root word is "bulong," which could mean medicine or healing. In the context of the prayer, however, it also connotes likeness. In one interview, a farmer claimed that the reason why such plants and bamboo installations are placed in the middle of the field is so that the bagong will take the likeness of such plants as the sugarcane and turmeric. Farmers believe that their crops will take the characteristics of the plants nearest them.

The planting material called butig (Figure 5) is buried in the soil. Only a part or one-half of the butig or tuber is covered with soil. Farmers stand on their feet without touching their knees when planting the butig (Figure 6). According to them, "Diri tumukod sa tuhod kay nadagko a lakop pareho sa kanan tuhod bulalo" (One shouldn't touch the knees because the lakop will grow as big as the kneecap). Farmers explained that what they want to harvest is a big iroy (mother root) with less lakop. Lakop is the part that is attached to the main root and is considered of less value since it is inedible. 
Folk Beliefs and Practices of Bagong

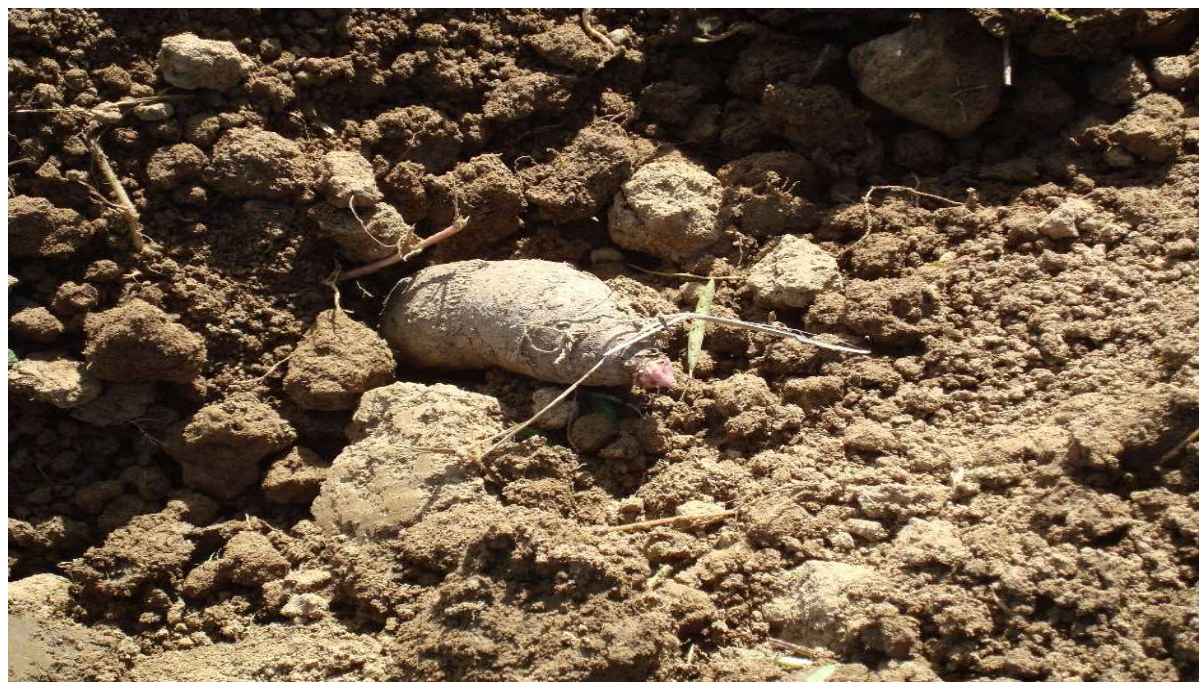

Figure 5. A butig during tadok

The planters make it a point not to scratch any part of their body as soon as they start with the ritual. This is the reason why they are particular with the time of planting: they go to their farms in the morning and avoid working in the afternoon because according to the farmers, "Daramo a nuknok sa kulop" (There are lots of gnats in the afternoon). They believe that the scratching would make bagong itchy and even cause burning sensations once eaten. Again, witnessed here is the belief that the crop assumes the characteristic of its environment and even its planter. $A$ wrong move during the ritual will spell disaster during harvest time.

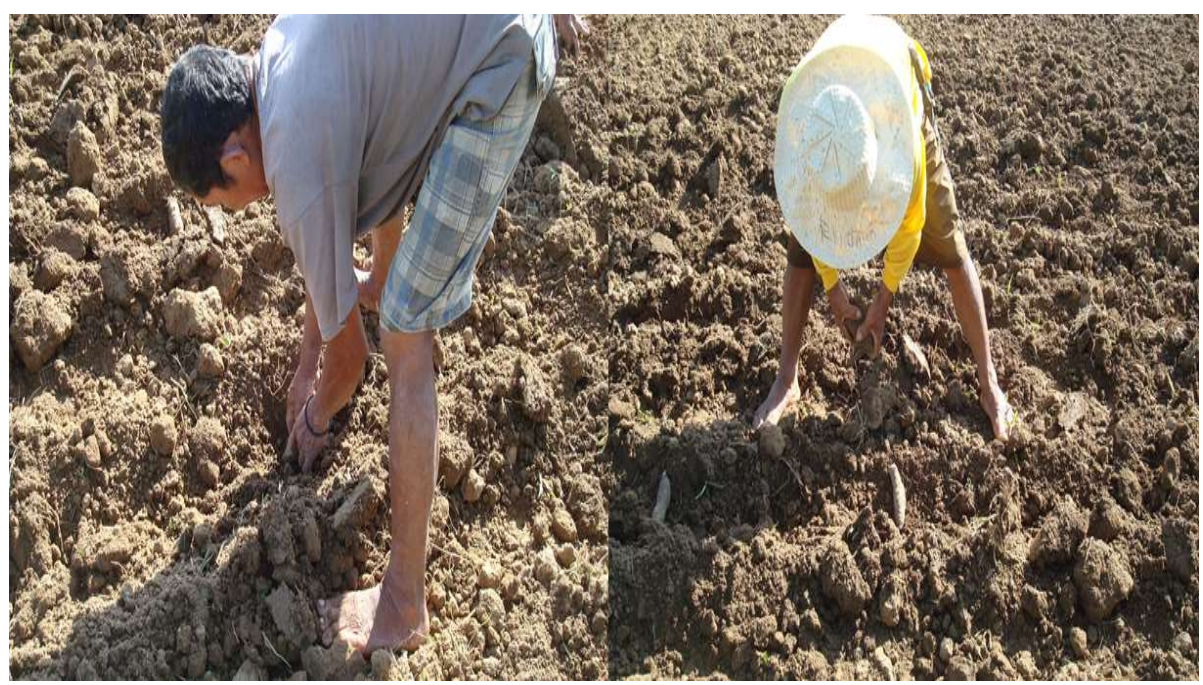

Figure 6 . When planting the butig, farmers stand on their feet, move backwards while planting, and avoid contact with their knees the entire time 


\section{Maintenance of the Bagong Farm}

The farmers claimed that having a bagong farm is like nagsagpon (being pregnant): they wait for eight to nine months before harvesting the plants. They further revealed that there used to be many bagong farmers in San Roque. One respondent from Barangay Balud said, "Sa una tag-traynta a nagtatanom. Yana nagtitigdito na. Luri iton nga tanom (Before there used to be about thirty bagong cultivators. Now, it has decreased. It is a sensitive plant)." It was noted that two of the oldest bagong cultivators were aged seventy-one (71) and eighty-three (83) years old (Figure 7) at the time of the study. When asked why they continue to plant despite the economic pressures and changing times, farmers would usually reply: "A bagong a oridyinal nga duma. Gidumahi. Primera klase. Gihahanap sa tawo (Bagong is the original root crop. The best. First class. People look for it)."

Maintaining a bagong farm is trabahoso (laborious), according to the farmers. They said, "Kada tulo ka adlaw, dalos" ("Every three days, it needs weeding"). They further added, "Kinahanglan siya atamanon basi mahiwarang. Nadiri siya matinong. Nagbabaga siya basta masighot. Diri nakatubo si maupay" (It should be maintained so the area will be free from grasses. It doesn't want competition. It turns red when there are grasses. It doesn't grow well.).

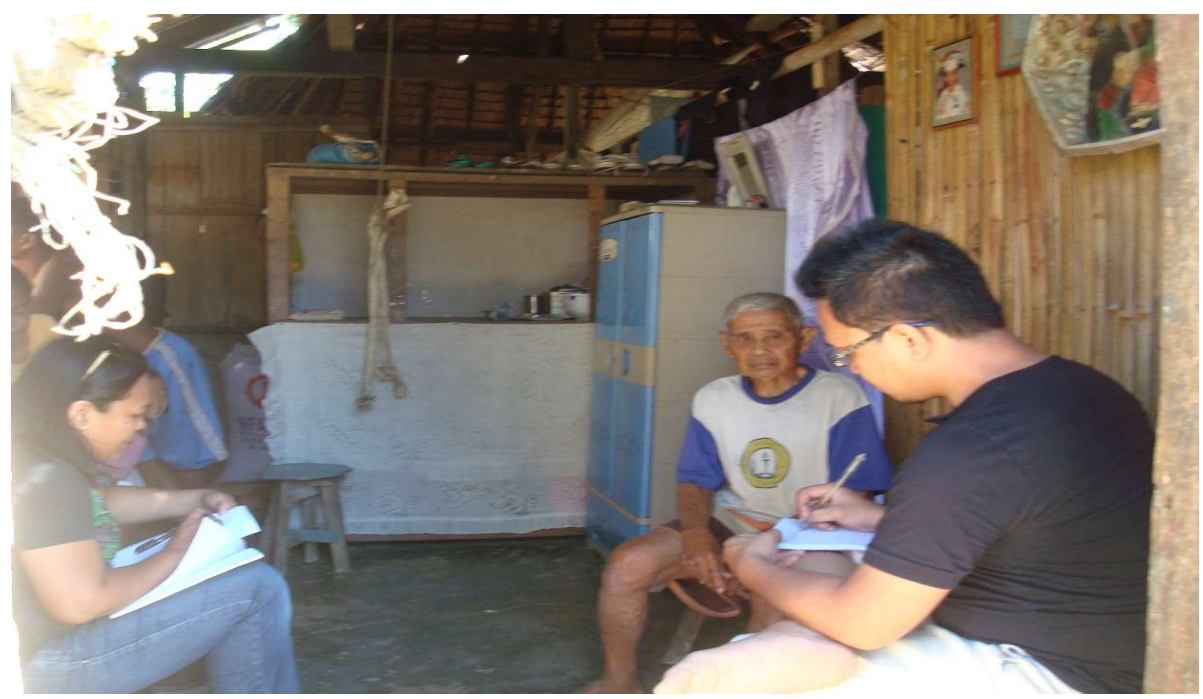

Figure 7. Mr. Enrique Dela Cruz, of Brgy. Coroconog, is the oldest bagong cultivator in San Roque

The farmers claimed that the best plant to intercrop with bagong is gaway or taro (Figure 8). They said, "A gaway mao a asawa sa bagong. Magpadis gud iton sira. Mag-angay sira. Maupay kanra tubo kun gipapadis. (Taro is the spouse of bagong. They really are partners. They complement each other. They grow well when they are planted together."). The farmers also revealed that although they have to do regular weeding in the farm, they do not water the plants be it during the initial planting or during the entire cropping season. In fact, bagong thrives better on mamara nga tuna or dry soil. 
Folk Beliefs and Practices of Bagong

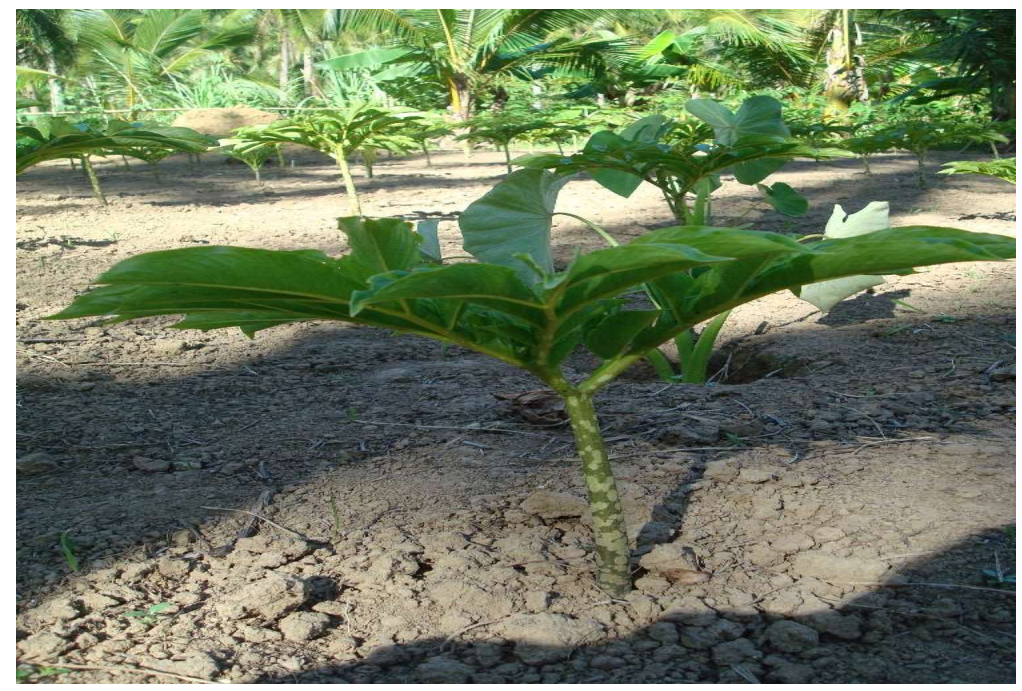

Figure 8. A one-month old bagong farm with some taro plants in Brgy. Coroconog

Aside from the regular weeding, the farmers also have to monitor their plants so nothing will be stolen from their farms. They try to prevent others from stealing their bagong, for they consider it a bad omen. They explained, "Naluya a semilya basta nakakawatan. Pang-un iton, diri puyde piriton ("The tubers produced are of low quality when a bagong is stolen. It brings bad luck. One shouldn't insist on using it.").

A farmer who experiences stealing in his farm does not plant any bagong in the next cropping season. To stop the bad fortune, he wraps one butig with pili nga dugnit (a black cloth). The black cloth is the pangontra sa sumpa or counter curse. The butig in black cloth is tied to a cut banana trunk which serves as a tabaw (raft). Then, the tabaw is released into the river. The farmer says a prayer which goes like this: "A kadisgrasyahn sini nga butig madara sa sulog sini nga sapa" (May the misfortune of this butig be carried by the river currents).

\section{Thanksgiving Ritual}

The farmers practice pagpahiabay (sharing the crop) on una nga ukad or the first harvest (Figure 9). They usually do their first harvest on November 1 in preparation for the celebration of All Souls Day on November 2. They cook the root crop the inug-og way or by adding coconut milk and sugar. Then, they bring the cooked bagong to the cemetery as an offering to kag-anak nga nagkamatay na (deceased ancestors). 


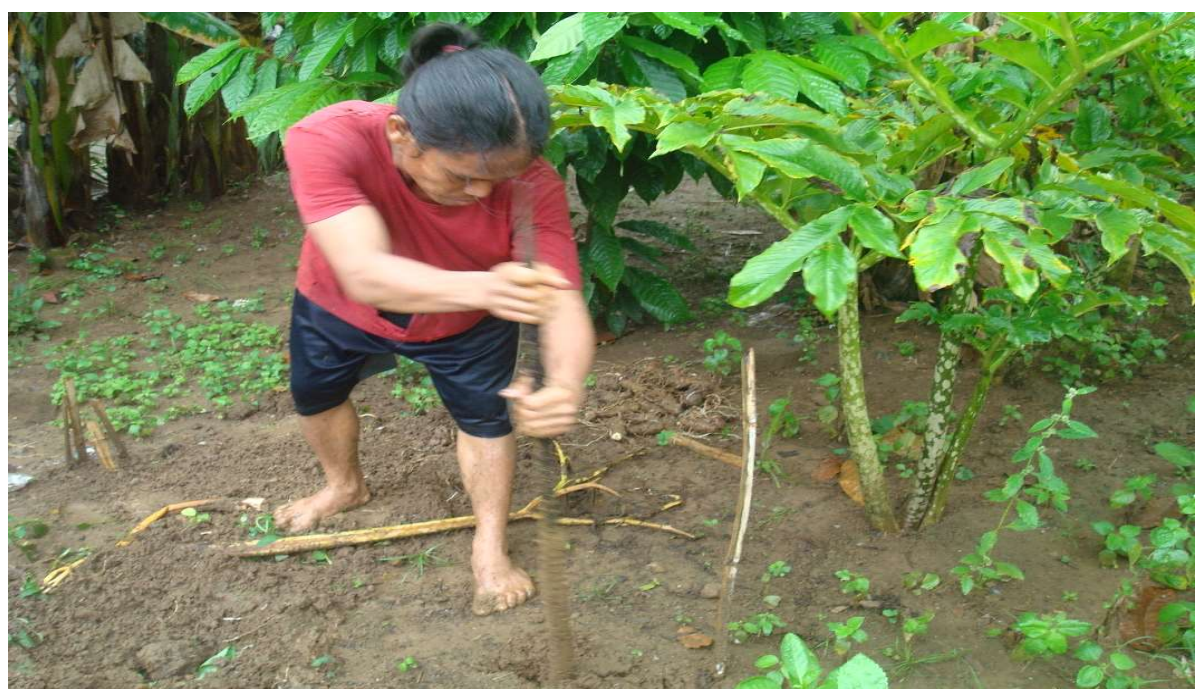

Figure 9. First harvest on November 1 in Brgy. Balud

Pagpahiabay is also extended to relatives and neighbors. One farmer gave a darahunon or proverb to make his point: "Kun magduduhong ka, pagduduhungan ka man" (If you will be selfish, life will be selfish to you).

\section{Bagong Storage}

After the first harvest, the farmers leave the rest of the root crops in the field (Figure 10). They do the next harvest only when it is needed, eg, whenever there are buyers who go to their farms or when they have to sell their produce in the market usually in San Roque, in Laoang, and in Catarman - or when they want to eat bagong.

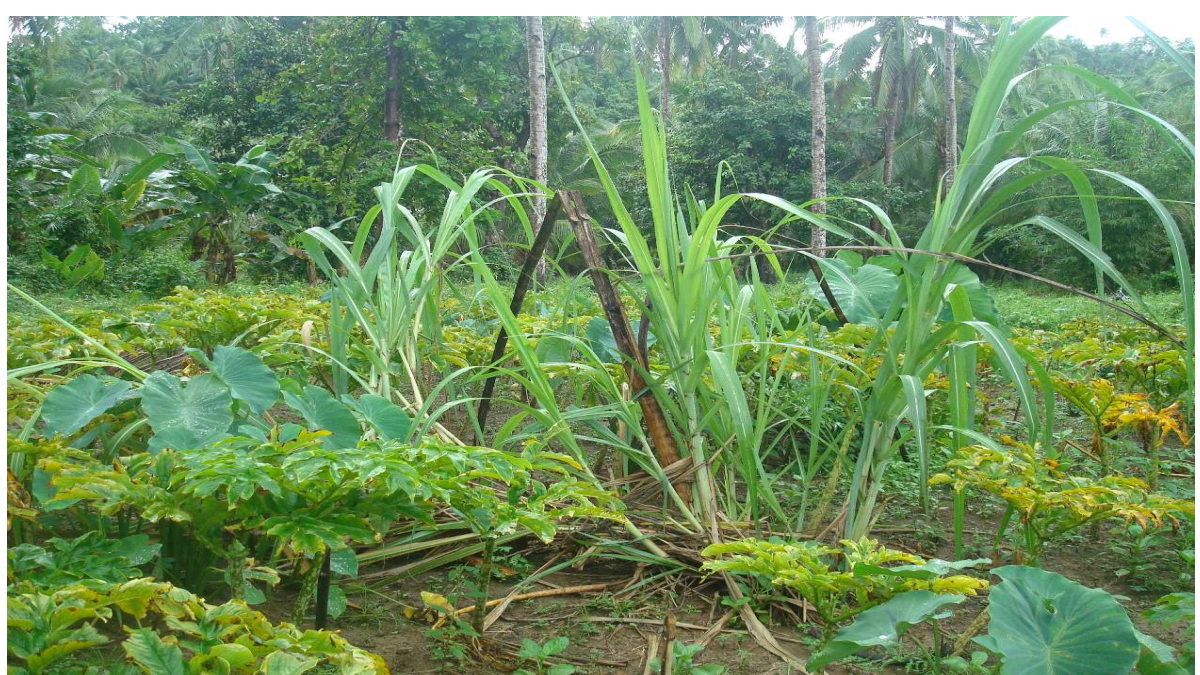

Figure 10. The rest of the bagong plants remain in the field after the first harvest. (The photo above shows the sariak and the grown sugarcane in the middle of the farm.) 
Folk Beliefs and Practices of Bagong

Consumers start looking for bagong when katkakanta-the time of the year when Christmas carols are sung, usually September-begins. But most of the farmers wait until December before they start releasing their produce. "Bagong a gitatamo sa pasko. Diri kumpleto a pasko kun waray bagong. Hasta pa sa bag-o nga tuig, bagong a gitatamo" (It's bagong that is served during Christmas. Without it, Christmas is not complete. Even during New Year, it is bagong that is also served.), said one bagong farmer in Brgy. Coroconog.

Unlike other root crops, however, bagong is neither stored in a container nor in a storage building. "Diri puyde ig-inayad" ("It cannot be stored somewhere else"), according to the farmers. They further said, "Maupay kun adto sa tuna" (It is good to leave them in the soil).

\section{Harvesting the Bagong}

Approximately seven (7) months after planting, the leaves of the bagong plant start to turn yellow. Then, its stalk falls off naturally. The farmer puts a bamboo stick on that area for monitoring purposes and to indicate that there is a bagong ready for harvest (Figure 11).

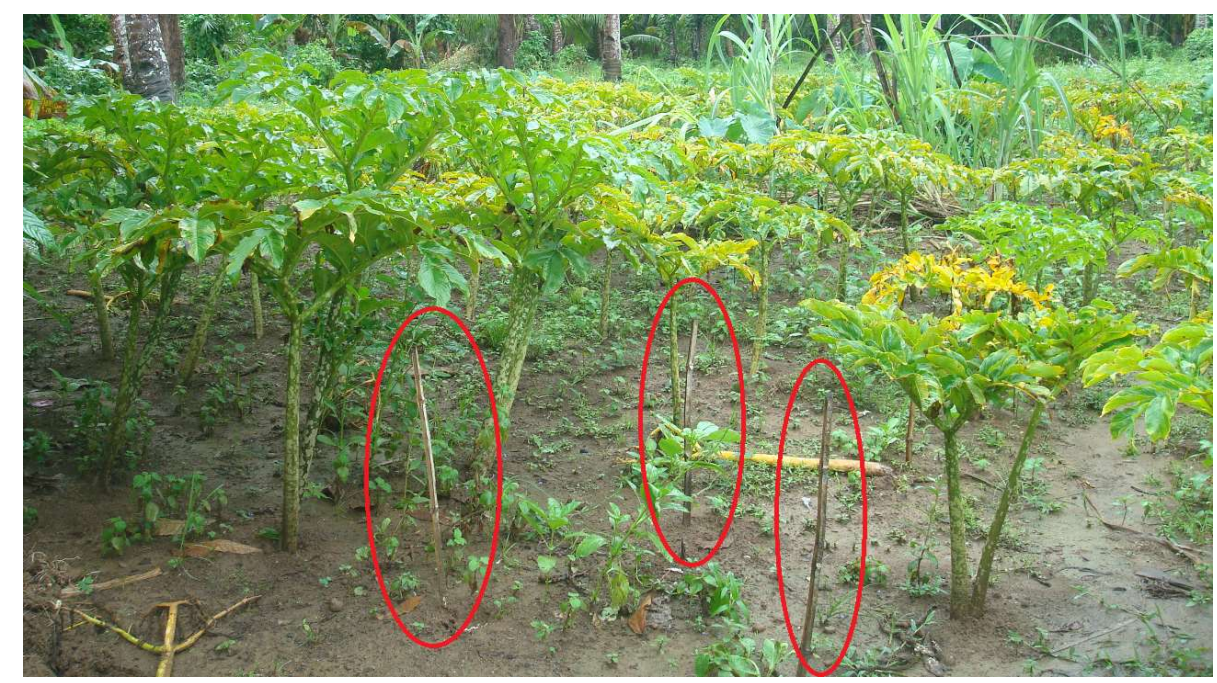

Figure 11. Bamboo sticks are placed on the areas where there are bagong crops to be harvested

Bagong is harvested with the use of a digging bar as shown in Figure 9. The root crops are then subjected to pagparonas (removal of the clay) with the use of bare hands. The farmers see to it that clay is not totally removed (Figure 12), especially if these are to be brought to the market, to keep them fresh and of good quality. 


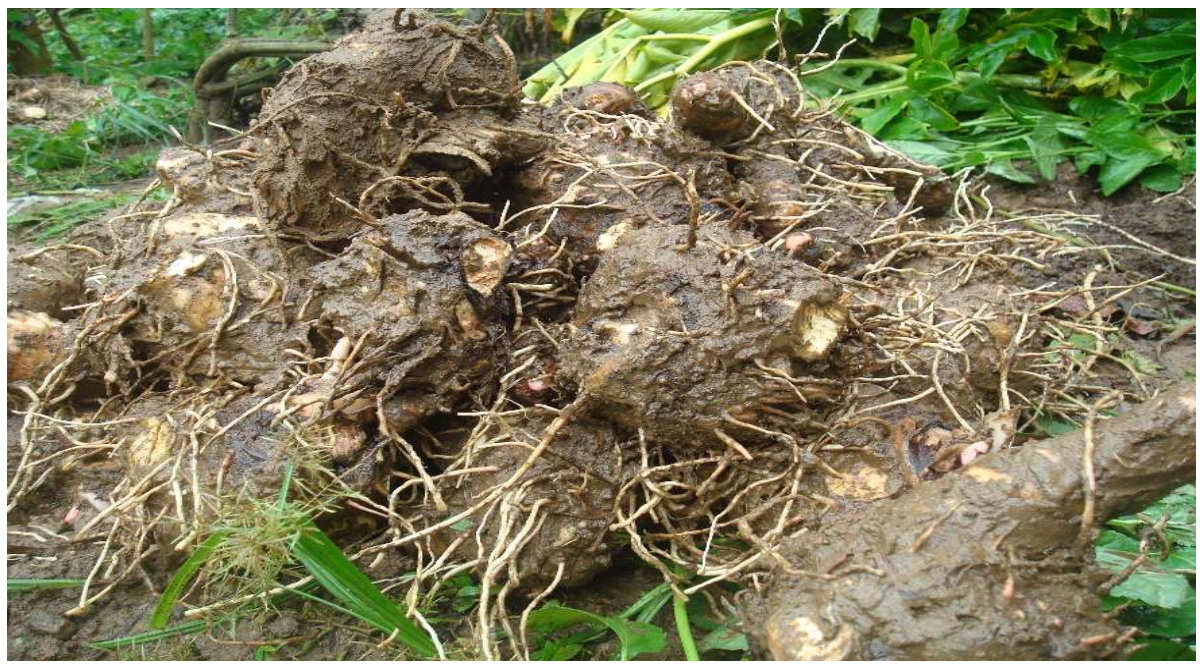

Figure 12. Bagong ready for pagparonas

\section{Securing the Tubers}

During pagparonas, the butig or tubers attached to the iroy (mother root) are removed. These are kept as planting materials for the next cropping season. They are placed on a pantaw [an elevated dry place made of bamboo slats (Figure 13 \& Figure 14). "Gitatapid" (They are arranged in rows), said the farmers.

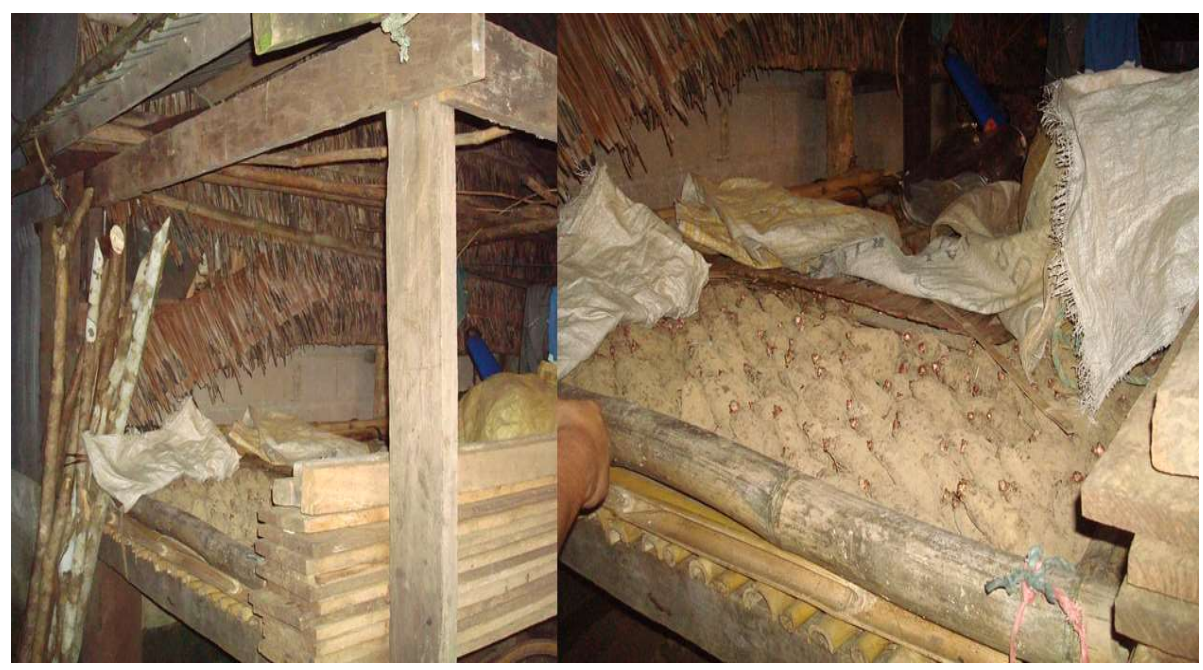

Figure 13. Planting materials on a pantaw in Brgy. Balnasan 
Folk Beliefs and Practices of Bagong

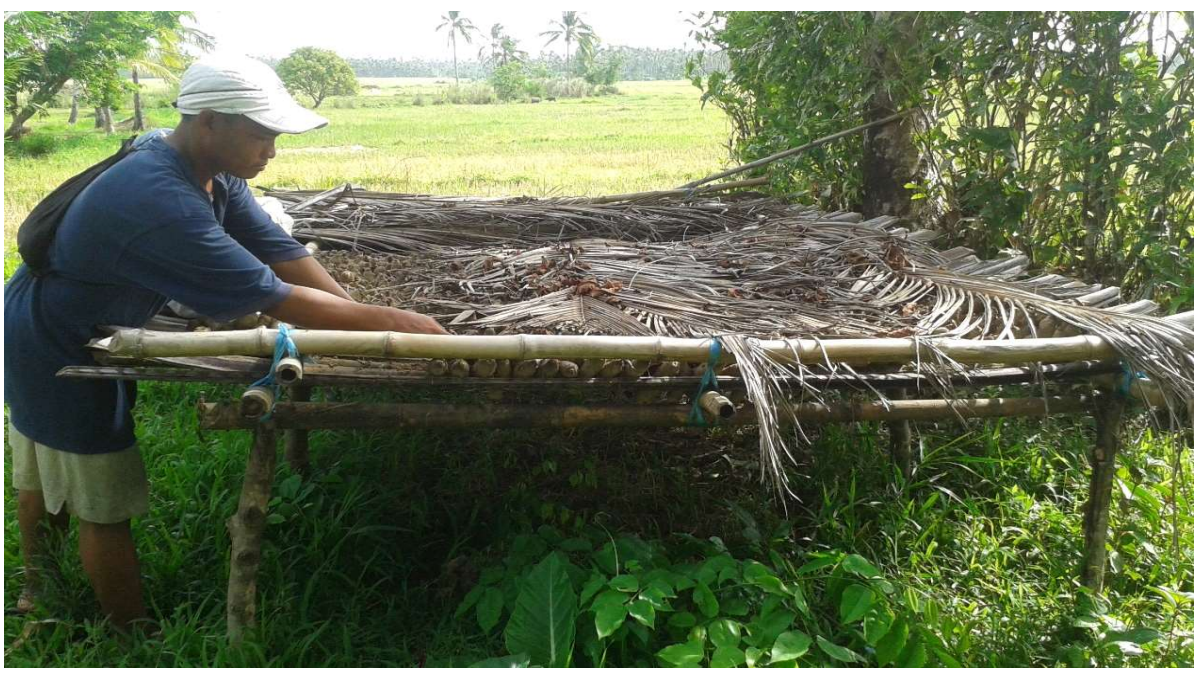

Figure 14. Planting materials on a pantaw in an open field in Brgy. Balud

To keep the planting materials healthy, wigtik tubig is done, ie, water is sprinkled on them and this is done in a very minimal manner.

\section{Bagong as Food}

Bagong is famously served as inug-og (Figure 15) during the Christmas season. Inug-og is any root crop cooked with coconut milk. There are two types of inug-og nga bagong: the inasin nga inug-og (salty inug-og) and the matam-is nga inug-og (sweet inug-og). According to the respondents, the latter is served during parties or special occasions and is more famous between the two.

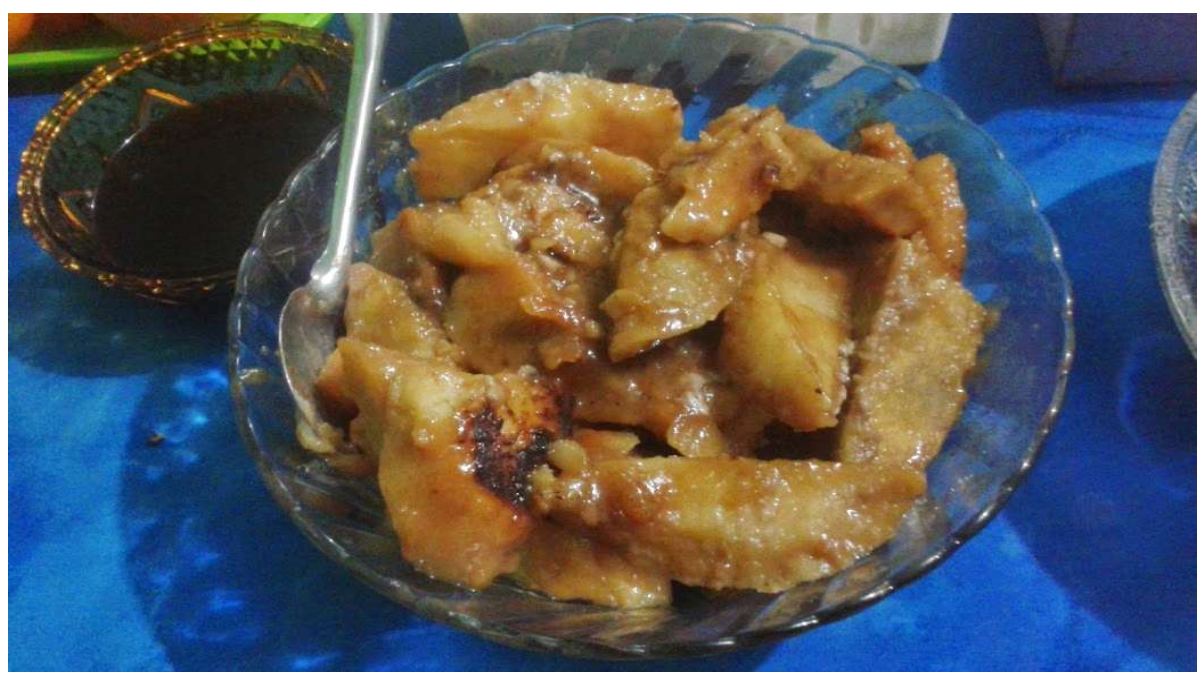

Figure 15. Inug-og nga bagong 
Locals start looking for bagong at the onset of the "ber months", ie, September to December. Respondents even revealed that Christmas in San Roque is incomplete if the person is not able to eat bagong; hence, the demand for the root crop. They added, "Diri na sikat a bagong sa Enero kay liwas na sa pasko" (There is no demand for bagong in January because it's beyond the Christmas season).

Bagong may also be served as pinasbo: the root crop is chopped into smaller pieces and cooked in plain water. Instead of sugar, some salt is added. Lemon grass may also be added. Respondents call this kinadaan (traditional) and does not appeal to the younger generation.

The stem (paklang) of a young bagong plant may also be utilized as food. It is delicious when it is cooked as linantod. Linantod is any main dish cooked in coconut milk and salt. However, not all respondents practice this because they would rather wait for the plant to grow into full maturity and sell it as a root crop, thereby getting more income. They disclosed that even the mature stems can still be utilized: these are chopped, boiled, and used as laun, ie, food for the pigs.

\section{CONCLUSIONS AND RECOMMENDATIONS}

Why do community traditions and folk practices such as those associated with bagong continue to this day? A reason for this lies in its mode of transmission: by word of mouth among a tightly knit group of families whose lives are sustained by the land and sea they rely on for daily subsistence (Dulawan 2005). The community of San Roque is the driving force behind the continuity of the bagong ritual, thereby assuring its survival into the next century.

Bagong cultivation continues because of the sense of attachment the people of San Roque have for the crop. Despite some challenges, farmers continue to plant bagong for varied reasons: gustatory, social, economic, or religious. Its importance in the community is evident in the fact that the residents consider it as part of their communal life.

With the onslaught of climate change that has transformed postmodern humanity in more ways we could imagine, it is imperative that the national government in particular and world governments in general look into areas that will be tremendously affected. One such area is food security where explorations into alternative food sources and food production methods should be in order. A good start towards this direction is to locate, innovate, and implement indigenous agricultural knowledge such as what the bagong farmers in this study would do in their own communities. Inscribed within a complex of folk beliefs and practices, these indigenous epistemologies should be read as they are: a people's centurieslong way of surviving and living with the harsh terrains of Northern Samar.

This study focused only on the bagong cultivators' knowledge about the folk beliefs and practices associated with bagong farming. The younger residents, especially those residing in the town proper, may not be fully aware of these; hence, a survey to assess their awareness may be conducted. Other studies such as yield every cropping season and nutrient content of the crop may also be helpful.

It is highly recommended that the Local Government Units of San Roque should establish an information center focusing on bagong production and its deeply entrenched sociality to raise public awareness. 
Folk Beliefs and Practices of Bagong

\section{ACKNOWLEDGMENTS}

We wish to thank the VSU Office of the Vice President for Research and Extension for providing us financial support in the conduct of this study. We would also like to thank the staff of the Municipal Office as well as the LGU municipal and barangay officials of San Roque, Northern Samar for giving us access to information. Special thanks go to the bagong farmers for the willingness to participate in the study and for accommodating the researchers into their homes and their communities.

\section{REFERENCES}

Alcina FI. 1668. History of the Bisayan people in the Philippine Islands. Manila, Philippines: UST Publishing House 2005

Arens R. 1956. Animistic fishing fitual in Leyte and Samar. Philippine Sociological Review 4(4):24-28

Arens R. 1957. The rice ritual in the East Visayan Islands, Philippines. Folklore Studies 16:268-290

Arens R. 1982. Folk practices and beliefs of Leyte and Samar. Tacloban City, Philippines: Divine Word University Publications

Chua M, Baldwin TC, Hocking TJ \& Chan K. 2010. Traditional uses and potential health benefits of Amorphophallus konjac $\mathrm{K}$. Koch ex $\mathrm{NE} \mathrm{Br}$. Journal of ethnopharmacology 128(2):268-278

Demetrio F. 1969. The engkanto belief: an essay in interpretation. Asian Folklore Studies 28(1):77-90

Dorugade S, Walawade M \& Kamble S. 2015. Toxicity of fungicides on Fusarium solani causing dry rot of elephant foot yam. International Journal of Advanced Research 3(6):1501-1504

Dulawan MB. 2005. Oral literature of the Ifugao. Manila, Philippines: National Commission for Culture and the Arts

Guinand Y and Lemessa D. 2001. Wild-food plants in Ethiopia: reflections on the role of wild foods and famine food at a time of drought. In Kenyatta $C$ and Anderson A (eds) The Potential of Indigenous Wild Foods (pp2-5). USAID/OFDA, Southern Sudan

Krishna RK, Krishnakumari S \& Chandrakala S. 2012. Evaluation of antioxidant properties of different parts of Amorphophallus commutatus, an endemic aroid of western ghats, south India. International Journal Pharm and Bio Sciences 3(3):443-455

Litsinger JA, Libetario EM \& Canapi BL. 2009. Eliciting farmer knowledge, attitudes, and practices in the development of integrated pest management programs for rice in Asia. In Integrated pest management: dissemination and impact ( $\mathrm{pp} 119$ 273). Springer, Dordrecht

Municipal Planning and Development Office. 2018. Municipality of San Roque, Northern Samar

Paul A, Arif SM, Biswas S, Islam MT, Al Arif MH, Kahali S \& Rahmatullah M. 2012. A survey of non-conventional plant items consumed during periods of food scarcity by low income groups in Atra village of Khulna district, Bangladesh. American-Eurasian Journal of Sustainable Agriculture 6(3):140-145 
Philippine Statistics Authority. 2016. Total Population by Province, City, Municipality, and Barangay as August 1, 2015. Retrieved November 20, 2018, from https://psa.gov.ph/content/highlights-philippine-population-2015census-population

Polo JB. 1983. The Binalayan Fishing Ritual-Drama. Tacloban City, Philippines: Divine Word University of Tacloban 